
ALEKSANDRA CEBULSKA ${ }^{1}$, AGNIESZKA GIMIŃSKA ${ }^{1}$, ANNA MOŃKO ${ }^{2}$

\title{
INFLUENCE OF NUTRITION OF PIGS WITH LEGUME-ENRICHED MIXTURES ON THE QUALITY OF PORK
}

\author{
WPŁYW ŻYWIENIA ŚWIŃ MIESZANKA Z UDZIAŁEM \\ ROŚLIN STRĄCZKOWYCH NA JAKOŚĆ MIĘSA WIEPRZOWEGO
}

\begin{abstract}
Summary
Background. More restrictive requirements concerning food production safety will bring about the process of withdrawing GM plants, including soya, from animal feed mixtures starting in 2017. At present, imported extracted soya meal is the base to make complete-portion mixtures used in pig feed. The soybean meal will have to be replaced by legumes produced in Poland. The aim of the research was a comparison of meat quality coming from pigs fed on complete-portion mixtures on the base of soya meal and complete-portion mixtures with an addition of pea and with an addition of lupine.

Material and methods. Meat of 32 crossbred fatteners $(\mathrm{plw} \times \mathrm{pl})$ was tested. Half of them were fed a soya-share diet (K) and the other (D) a $20-38.5 \%$ pea and lupine share diet. In the longissimus lumborum muscle the $\mathrm{pH}_{45}$ and $\mathrm{pH}_{48 \mathrm{~h}}$ values and basic chemical composition were determined, as well as technological properties of the meat. The colour of the meat was also analysed with Minolta CR 310 apparatus, as well as sensorially, while its marbling and firmness were tested only sensorially.

Results. The assessed meat from both groups, i.e. control (K) and experimental (D), displayed good technological and sensorial properties and colour parameters. Moreover, the meat was tender with a beneficial protein and intramuscular fat content.

Conclusion. No negative influence on obtaining good quality meat without any significant differentiation in its parameters was observed from substituting soybean meal for legume seeds in feed mixture.
\end{abstract}

Key words: legume seeds, pork meat, physical characteristics, meat quality 
Bocian, M., Kapelański, W., Adamowicz, M., Jankowiak, H., Cebulska, A., Gimińska, A., Mońko, A. (2016). Influence of nutrition of pigs with legume-enriched mixtures on the quality of pork. Nauka Przyr. Technol., 10, 4, \#46. DOI: http://dx.doi.org/10.17306/J.NPT.2016.4.46

\section{Introduction}

Pork meat quality depends on genetic and environmental factors. Animal feeding is important as much as other factors. At present, imported soya meal is the base to make complete-portion mixtures used in pig feed. The exported soybean meal will have to be replaced by protein of legumes produced in Poland. There will be a ban on introducing fodders originating from genetically modified plants onto the Polish market starting from January 1, 2017. An alternative to the imported soya may be the Polish protein source i.e. leguminous plants seeds: pea, faba bean, lupine or rape extracted meal (Rutkowski et al., 2014). Pork meat quality includes numerous aspects, e.g.: health safety, nutritious value, its technological properties, as well as sensorial characteristics. Yet, a distinguishing mark of both technological and consumption quality of meat is its colour which directly influences the purchasing decision of a customer (Bocian et al., 2015; Pospiech, 2016). Pork consumers pay attention not only to the quality of meat but also, more and more frequently, concentrate themselves on limiting their consumption of genetically modified plants mixture-fed pigs meat (Pospiech, 2016). Research on the problem of fatteners fed a feed mixture with a differentiated share of legumes indicates obtaining a good quality meat without a meaningful differentiation in its parameters (Chrenková et al., 2011; Hanczakowska and Świątkiewicz, 2014; Kim et al., 2010; Mordenti et al., 2012; Sokół et al., 2001; Zralý et al., 2006).

The aim of the research was a description of the influence on pork quality of soyben meal substitution for leguminous plants seeds in pig diet.

\section{Material and methods}

Meat from 32 crossbred $\mathrm{F}_{1}(\mathrm{plw} \times \mathrm{pl})$ fatteners was tested.

Differentiated feeding was applied to pigs during fattening: the control group $(\mathrm{K})$ was fed with no limits with complete-portion fodder prepared on the base of soya oil meal, whereas fatteners from the experimental group (D) were fed a mixture with a share of legumes, in agreement with the norms for pigs feeding (Grela and Skomiał, eds., 2015).

The protein component in prepared experimental mixtures consisted of: $20 \%$ pea, $37.6 \%$ lupin (fattening stage I), and $38.5 \%$ pea and $20 \%$ lupin (fattening stage II). Each group consisted of 16 fatteners, $50 \%$ gilts and $50 \%$ hogs.

Fattening was completed at body mass approx. 105-120 kg. After the fattening had been completed, the animals were transported to a $10 \mathrm{~km}$ distant slaughter house. The slaughter was carried out between April-September, 2015.

Stunning of animals was conducted by help of Letterschmidt-Weinberger's forceps, according to the standards and regulations in force.

Assessment of meat quality was carried out on samples of longissimus lumborum muscle taken from carcasses selected $24 \mathrm{~h}$ after the slaughter. Measurements of acidity were conducted twice in the longissimus lumborum muscle: after $45 \mathrm{~min}\left(\mathrm{pH}_{45}\right)$ and $48 \mathrm{~h}$ $\left(\mathrm{pH}_{48 \mathrm{~h}}\right)$ after the slaughter, applying CP-401 $\mathrm{pH}$-meter produced by Elmetron company 
Bocian, M., Kapelański, W., Adamowicz, M., Jankowiak, H., Cebulska, A., Gimińska, A., Mońko, A. (2016). Influence of nutrition of pigs with legume-enriched mixtures on the quality of pork. Nauka Przyr. Technol., 10, 4, \#46. DOI: http://dx.doi.org/10.17306/J.NPT.2016.4.46

and equipped with a bodkin electrode. The apparatus was calibrated using the Elmetron's buffer of $\mathrm{pH} 7.0$ and $\mathrm{pH} 4.0$.

Assessment of water holding capacity was performed applying the method according to Grau and Hamm (1952) in Pohja and Niinivaara's (1957) modification. A sample of comminuted meat of $300 \mathrm{~g}$ mass was placed on blotting paper of Whatman 1 type, next it was situated between two glass plates and subjected to an even load of $2 \mathrm{~kg}$ for 5 min.

The percentage of free water in meat was assessed from the size of the drip surface, assuming that $1 \mathrm{~cm}^{2}$ of the drip corresponded to $10 \mathrm{mg}$ of water. A smaller drip surface (free water quantity) indicates a higher meat water holding capacity.

Free drip of meat juice in the course of $48 \mathrm{~h}$ of storage was made according to Honikel (1987) on slices $2.5 \mathrm{~cm}$ thick including peri- and epimysium. The sample was placed in a plastic foil bag and weighed. The lower part of the bag was perforated in a few places to make the muscle juice flow out. Next, the sample was placed in another bag, and hung in the manner preventing the flowing out juice from contact with the meat sample.

The samples were stored in the hanging position at $2-4^{\circ} \mathrm{C}$, for $48 \mathrm{~h}$. The samples were weighed again after that time. The value of free drip of juice from the meat was then assessed on the basis of the difference of the mass before storing and after $48 \mathrm{~h}$ storing.

The value of the thermal drip was assessed $48 \mathrm{~h}$ after the slaughter applying Walczak's (1959) method. A sample of comminuted meat (20 g) was placed in hygroscopic gauze and warmed up in water bath at $85^{\circ} \mathrm{C}$, for $10 \mathrm{~min}$. The sample was weighed, after it had been taken out, cooled down to $4^{\circ} \mathrm{C}$ and the gauze removed.

Its percentage loss was assessed from the difference of the meat mass before heat processing and after it. The meat tenderness of cooked meat was estimated using INSTRON 3342 apparatus with Warner-Bratzler shear force equipment countershaft, following the methodology given by Szalata et al. (1999).

A meat sample of approx. $120 \mathrm{~g}$ was heated in water bath till the moment $70^{\circ} \mathrm{C}$ temperature was reached in its interior. Heat processing was conducted in $\mathrm{NaCl}$ solution, at $0.85 \%$ concentration.

Afterwards, muscle fibre direction-wise, matchsticks $10 \mathrm{~mm} \times 10 \mathrm{~mm}$ were cut out which were then subjected to cutting perpendicularly to their direction. The results were read as maximum shear force, expressed in newtons per $1 \mathrm{~cm}$.

The analysis of the chemical composition of meat i.e.: water, total protein, and intramuscular fat, was carried out in compliance with the norms (PN-A-82109:2010, 2010), applying the method of transmissional spectrophotometry in near infrared radiation (NIT), using artificial neural networks calibration by help of FoodScan apparatus produced by FOSS company.

The following were assessed visually on a $120 \mathrm{~g}$ slice of meat: colour intensity according to 6-degree scale (PN-ISO 4121:1998, 1998): 1 point - very light colour meat, 6 points - dark-purple meat; degree of marbling by help of Canadian and American patterns in 10-degree scale (NPB, 2000): 1 point - meat without double muscling, 10 points - meaningful marbling; firmness - meat toughness in 7-degree scale (PN-ISO 4121:1998, 1998): 1 - very tough, 7 - very soft. 
Bocian, M., Kapelański, W., Adamowicz, M., Jankowiak, H., Cebulska, A., Gimińska, A., Mońko, A. (2016). Influence of nutrition of pigs with legume-enriched mixtures on the quality of pork. Nauka Przyr. Technol., 10, 4, \#46. DOI: http://dx.doi.org/10.17306/J.NPT.2016.4.46

The meat colour was also measured on a raw meat slice, $48 \mathrm{~h}$ after slaughter, by help of photo colorimeter Minolta CR 310 (Konica Minolta, Japan): of $50 \mathrm{~mm}$ in diameter of the measuring port. The standardization of the apparatus was carried out applying a white Minolta CR 310 model plate of $\mathrm{Y}=92.80, \mathrm{x}=0.3175$ and $\mathrm{y}=0.3333$ coordinates.

The colour parameters were described in the CIE $L^{*} a^{*} b^{*}$ system $\left(L^{*}-\right.$ lightness, $a^{*}$ - participation of red, $b^{*}$ - participation of yellow) (CIE, 1986), applying D65 illuminate and standard observer $2^{\circ}$. Colour saturation (parameter $C^{*}$ ), as well as colour shade ( $h^{\circ}$ - hue angle) were estimated according to the formula given by Beattie et al. (1999) and Brewer et al. (2001):

$$
C^{*}=\sqrt{\left(a^{*}\right)^{2}+\left(b^{*}\right)^{2}}, h^{\circ}=\left(\tan ^{-1} b^{* / a^{*}}\right)
$$

The obtained results were statistically computed, estimating the arithmetic mean and standard deviation for each of the characteristics. The significance of differences between the data of groups K and D was verified using t Student's test. Statistica 8 PL program was applied for the calculations (STATISTICA..., 2008).

\section{Results and discussion}

Characteristics of technological suitability of meat depending upon the applied mixture in pigs feeding are presented in Table 1. No significant differentiation of the investigated features between the groups was found. The meat acidity, water holding capacity and free juice drip were normal.

Table 1. Characteristics of the technological suitability of meat Tabela 1. Charakterystyka przydatności technologicznej mięsa

\begin{tabular}{|l|c|c|}
\hline \multicolumn{1}{|c|}{$\begin{array}{c}\text { Trait } \\
\text { Cecha }\end{array}$} & $\begin{array}{c}\text { K } \\
\text { Control group } \\
\text { Grupa kontrolna }\end{array}$ & $\begin{array}{c}\text { D } \\
\text { Experimental group } \\
\text { Grupa doświadczalna }\end{array}$ \\
\hline \multicolumn{1}{|c|}{1} & 2 & 3 \\
\hline $\mathrm{pH}_{45}$ & $6.31 \pm 0.05$ & $6.32 \pm 0.04$ \\
$\mathrm{pH}_{48 \mathrm{sh}}$ & $5.40 \pm 0.05$ & $5.43 \pm 0.08$ \\
Water holding capacity (\% of free water) & $20.13 \pm 3.86$ & $20.64 \pm 1.96$ \\
Wodochłonnośc (\% wody wolnej) & & $4.34 \pm 1.90$ \\
Free juice drip (\%) & $4.60 \pm 1.06$ & $21.91 \pm 2.68$ \\
Swobodny wyciek soku (\%) & $20.50 \pm 3.22$ & $41.75 \pm 10.22$ \\
Thermal drip (\%) & & \\
Wyciek termiczny (\%) & $40.43 \pm 9.36$ & \\
Shear force (N/cm) & & \\
Kruchość (N/cm) & & \\
\hline
\end{tabular}


Bocian, M., Kapelański, W., Adamowicz, M., Jankowiak, H., Cebulska, A., Gimińska, A., Mońko, A. (2016). Influence of nutrition of pigs with legume-enriched mixtures on the quality of pork. Nauka Przyr. Technol., 10, 4, \#46. DOI: http://dx.doi.org/10.17306/J.NPT.2016.4.46

Table 1 - cont. / Tabela $1-$ cd.

\begin{tabular}{|l|c|c|}
\hline \multicolumn{1}{|c|}{1} & 2 & 3 \\
\hline $\begin{array}{l}\text { Chemical composition of meat } \\
\text { Skład chemiczny mięsa }\end{array}$ & & \\
Water content (\%) & $73.11 \pm 0.70$ & $73.27 \pm 0.3$ \\
Zawartość wody (\%) & & $23.46 \pm 0.79$ \\
$\begin{array}{l}\text { Total protein content (\%) } \\
\text { Zawartość białka ogólnego (\%) }\end{array}$ & $23.47 \pm 0.66$ & $2.27 \pm 0.86$ \\
$\begin{array}{l}\text { Intramuscular fat content (\%) } \\
\text { Zawartość tłuszczu śródmięśniowego (\%) }\end{array}$ & $2.44 \pm 1.07$ & \\
\hline
\end{tabular}

Moreover, the meat was tender with a proper share of nutritious components i.e. protein and intramuscular fat. Chrenková et al. (2011), while applying $30 \%$ pea mixture to pigs feeding did not show any differentiation in meat quality characteristics: $\mathrm{pH}_{45}$, free juice drip, tenderness, nor in the chemical composition (water, protein and fat).

Zralý et al. (2006) applying a 10\% lupin addition in pig diet, obtained a lower total protein content $(21.97 \%)$ compared to the results of the below test. Yet, the authors proved a favourable effect of the applied 10\% lupin addition on both tenderness and flavour.

The research of Mordenti et al. (2012) also showed a lower percentage of protein $(21.27 \%)$ in meat of pigs fed with protein substitute (pea) than in those fed with extracted soya meal.

The results of the sensorial meat assessment, as well as colour parameters are included in Table 2. The assessed meat samples were light red, showed minimal marbling and very good firmness. No significant changes in the colour of meat $L^{*} a^{*} b^{*}$ were observed, nor in the saturation $C^{*}$ and colour shade $h^{\circ}$ between the two groups.

The obtained values were typical for normal quality meat (Bocian et al., 2015; Warriss et al., 2006). Similar observations were delivered by other researchers (Chrenková et al., 2011; Hanczakowska and Świątkiewicz, 2014; Mordenti et al., 2012). The experiment

Table 2. Results of sensorial analysis of meat and colour parameters

Tabela 2 . Wyniki oceny sensorycznej mięsa oraz parametry barwy

\begin{tabular}{|c|c|c|}
\hline $\begin{array}{l}\text { Trait } \\
\text { Cecha }\end{array}$ & $\begin{array}{c}\mathrm{K} \\
\text { Control group } \\
\text { Grupa kontrolna }\end{array}$ & $\begin{array}{c}\mathrm{D} \\
\text { Experimental group } \\
\text { Grupa doświadczalna }\end{array}$ \\
\hline 1 & 2 & 3 \\
\hline $\begin{array}{l}\text { Visual colour intensity (1-6 scale) } \\
\text { Intensywność barwy (skala 1-6) }\end{array}$ & $3.44 \pm 0.39$ & $3.35 \pm 0.27$ \\
\hline $\begin{array}{l}\text { Marbling (1-10 scale) } \\
\text { Marmurkowatość (skala 1-10) }\end{array}$ & $2.61 \pm 0.52$ & $2.32 \pm 0.47$ \\
\hline $\begin{array}{l}\text { Firmness (1-7 scale) } \\
\text { Jędrność (skala 1-7) }\end{array}$ & $4.43 \pm 0.53$ & $4.45 \pm 0.64$ \\
\hline
\end{tabular}


Bocian, M., Kapelański, W., Adamowicz, M., Jankowiak, H., Cebulska, A., Gimińska, A., Mońko, A. (2016). Influence of nutrition of pigs with legume-enriched mixtures on the quality of pork. Nauka Przyr. Technol., 10, 4, \#46. DOI: http://dx.doi.org/10.17306/J.NPT.2016.4.46

Table 2 - cont. / Tabela 2 - cd.

\begin{tabular}{|l|c|c|}
\hline \multicolumn{1}{|c|}{1} & 2 & 3 \\
\hline $\begin{array}{l}\text { Colour parameters } \\
\text { Parametry barwy }\end{array}$ & & \\
$L^{*}-$ lightness - jasność & $54.63 \pm 1.70$ & $54.46 \pm 1.43$ \\
$a^{*}-$ redness - udział barwy czerwonej & $15.47 \pm 0.73$ & $15.17 \pm 0.71$ \\
$b^{*}-$ yellowness - udział barwy żółtej & $3.06 \pm 0.56$ & $2.81 \pm 0.79$ \\
$C^{*}-$ chroma - nasycenie & $15.79 \pm 1.06$ & $15.44 \pm 0.71$ \\
$h^{\circ}-$ hue angle - ton barwy & $11.21 \pm 1.79$ & $10.52 \pm 2.90$ \\
\hline
\end{tabular}

carried out by Stein et al. (2006) proved a favourable impact of the mixture with $66 \%$ share of pea, applied at the end of fattening. The obtained colour was darker and more desirable, and the juice drip from meat was decreased. No negative influence was shown by Mordenti et al. (2012) on the meat colour (saturation and shade), when substituting extracted soya meal by leguminous plants seeds protein e.g. pea.

\section{Conclusions}

No negative impact of feeding pigs with a complete fodder mixture with a share of leguminous plants seeds on forming meat quality characteristics has been proved in the work. It is concluded that leguminous plants seeds in pig diet may successfully replace extracted soya meal without any negative influence on meat characteristics, which has been confirmed by the carried out investigations.

\section{References}

Beattie, V. E., Weatherup, R. N., Moss, B. W., Walker, N. (1999). The effect of increasing carcass weight of finishing boars and gilts on joint composition and meat quality. Meat Sci., 52, 2, 205-211. DOI: http://dx.doi.org/10.1016/S0309-1740(98)00169-7

Bocian, M., Jankowiak, H., Kapelański, W. (2015). Zmiany barwy mięsa w trakcie przechowywania. Nauka Przyr. Technol., 9, 4, \#57. DOI: 10.17306/J.NPT.2015.4.57

Brewer, M. S., Zhu, L. G., Bidner, B., Meisinger, D. J., McKeith, F. K. (2001). Measuring pork color: effects of bloom time, muscle, $\mathrm{pH}$ and relationship to instrumental parameters. Meat Sci., 57, 2, 169-176.

Chrenková, M., Formelová, Z., Chrastinová, L., Fl’ak, P., Čerešňáková, Z., Lahučký, R., Poláčiková, M., Bahelka, I. (2011). Influence of diets containing raw or extruded peas instead of soybean meal on meat quality characteristics in growing-finishing pigs. Czech J. Anim. Sci., 56, 3, 119-126.

CIE. (1986). Colorimetry. Publication CIE 15.2. Vienna: Central Bureau of CIE.

Grau, R., Hamm, R. (1952). Eine einfache Methode zur Bestimmung der Wasserbindung in Fleisch. Fleischwirtschaft, 4, 295-297. 
Bocian, M., Kapelański, W., Adamowicz, M., Jankowiak, H., Cebulska, A., Gimińska, A., Mońko, A. (2016). Influence of nutrition of pigs with legume-enriched mixtures on the quality of pork. Nauka Przyr. Technol., 10, 4, \#46. DOI: http://dx.doi.org/10.17306/J.NPT.2016.4.46

Grela, E. R., Skomiał, J. (eds.). (2015). Zalecenia żywieniowe i wartość pokarmowa pasz dla świń. Normy żywienia świń. Jabłonna: IFiŻZ PAN.

Hanczakowska, E., Świątkiewicz, M. (2014). Legume seeds and rapeseed press cake as replacers of soybean meal in feed for fattening pigs. Ann. Anim. Sci., 14, 4, 921-934. DOI: 10.2478/ao as-2014-0068

Honikel, K. O. (1987). The water binding of meat. Fleischwirtschaft, 67, 9, 1098-1102.

Kim, J. C., Mullan, B. P., Nicholls, R. R., Pluske, J. R. (2010). Effect of Australian sweet lupin (Lupinus angustifolius L.) inclusion levels and enzyme supplementation on the performance, carcass composition and meat quality of grower/finisher pigs. Anim. Prod. Sci., 51, 1, 37-43. DOI: dx.doi.org/10.1071/AN10087

Mordenti, A. L., Martelli, G., Brogna, N., Nannoni, E., Vignola, G., Zaghini, G., Sardi, L. (2012). Effects of a soybean-free diet supplied to Italian heavy pigs on fattening performance, and meat and dry-cured ham quality. Ital. J. Anim. Sci., 11, 4, e80, 459-465.

NPB. (2000). Pork composition and quality assessment procedures. Des Moines, IA: EP Berg National Pork Board.

PN-A-82109:2010. (2010). Mięso i przetwory mięsne - Oznaczenie zawartości thuszczu, białka i wody - Metoda spektrometrii transmisyjnej w bliskiej podczerwieni (NIT) z wykorzystaniem kalibracji na sztucznych sieciach neuronowych (ANN). Warszawa: PKN.

PN-ISO 4121:1998. (1998). Analiza sensoryczna. Ocena produktów spożywczych przy użyciu metod skalowania. Warszawa: PKN.

Pohja, M. S., Niinivaara, F. P. (1957). Die Bestimmung der Wasserbindung des Fleisches mittels der Konstantdruckmethode. Fleischwirtschaft, 9, 193-195.

Pospiech, E. (2016). Jakość mięsa i tłuszczu a image mięsa. In: W. Kiernożycki, E. Herbut, W. Olech (eds.), IX Szkoła Zimowa „Od hodowli świń do przetwórstwa - wczoraj i dziś”. Ustroń, 16-19 lutego 2016 (pp. 54-64). Szczecin: Wyd. ZUT.

Rutkowski, A., Kasprowicz-Potocka, M., Mikuła, R., Hejdysz, M. (2014). Możliwości zastosowania nasion roślin strączkowych w żywieniu zwierząt gospodarskich. Warszawa: Fundacja Programów Pomocy dla Rolnictwa FAPA.

Sokół, J. L., Bobel, B. K., Fabijańska, M., Bekta, M. (2001). Preliminary results on the influence of amaranthus seeds on carcass and meat quality of fatteners. J. Anim. Feed Sci., 10, Suppl. 2, 203-208.

STATISTICA (data analysis software system). Version 8. (2008). Kraków: StatSoft.

Stein, H. H., Everts, A. K. R., Sweeter, K. K., Peters, D. N., Maddock, R. J., Wulf, D. M., Pedersen, C. (2006). The influence of dietary field peas (Pisum sativum L.) on pig performance, carcass quality, and the palatability of pork. J. Anim. Sci., 84, 11, 3110-3117. DOI: 10.2527/ jas.2005-744

Szalata, M., Pospiech, E., Łyczyński, A., Urbaniak, M., Frankiewicz, A., Mikołajczak, B., Medyński, A., Rzosińska, E., Bartkowiak, Z., Danyluk, B. (1999). Kruchość mięsa świń o zróżnicowanej mięsności. Rocz. Inst. Przem. Mięsn. Tłuszcz., 36, 61-76.

Walczak, Z. (1959). Laboratoryjna metoda oznaczenia zawartości galarety w konserwach mięsnych. Rocz. Nauk Roln. Ser. B, 74, 4, 619-621.

Warriss, P. D., Brown, S. N., Paściak, P. (2006). The colour of the adductor muscle as a predictor of pork quality in the loin. Meat Sci., 73, 4, 565-569.

Zralý, Z., Pisaříková, B., Trčková, M., Herzig, I., Jůzl, M., Simeonovová, J. (2006). Effect of lupine and amaranth on growth efficiency, health, and carcass characteristics and meat quality of market pigs. Acta Vet. Brno, 75, 3, 363-372. DOI: 10.2754/avb200675030363 
Bocian, M., Kapelański, W., Adamowicz, M., Jankowiak, H., Cebulska, A., Gimińska, A., Mońko, A. (2016). Influence of nutrition of pigs with legume-enriched mixtures on the quality of pork. Nauka Przyr. Technol., 10, 4, \#46. DOI: http://dx.doi.org/10.17306/J.NPT.2016.4.46

\title{
WPŁYW ŻYWIENIA ŚWIŃ MIESZANKA Z UDZIAŁEM ROŚLIN STRĄCZKOWYCH NA JAKOŚĆ MIĘSA WIEPRZOWEGO
}

\begin{abstract}
Streszczenie
Wstęp. Wzrost wymogów w zakresie bezpieczeństwa żywności przyczynia się do wycofania z żywienia zwierząt od 2017 roku pasz sporządzonych z roślin genetycznie modyfikowanych, w tym z soi. Obecnie w żywieniu świń stosuje się mieszanki pełnoporcjowe sporządzane na bazie importowanej poekstrakcyjnej śruty sojowej, którą należy zastąpić nasionami strączkowymi produkowanymi w kraju. Celem badań było porównanie jakości mięsa świń żywionych mieszankami pełnoporcjowymi na bazie śruty sojowej i mieszankami pełnoporcjowymi $\mathrm{z}$ dodatkiem grochu i z dodatkiem łubinu.

Material i metody. Badano mięso 32 tuczników mieszańców (wbp $\times$ pbz), z których połowa otrzymywała dietę z udziałem soi $(\mathrm{K})$ i połowa dietę z udziałem od $20 \%$ do $38,5 \%$ grochu i łubinu (D). W mięśniu longissimus lumborum oznaczono wartość $\mathrm{pH}_{45}, \mathrm{pH}_{48 \mathrm{~h}}$ i podstawowy skład chemiczny mięsa oraz jego właściwości technologiczne. Analizowano również aparaturowo (Minolta CR 310) i sensorycznie barwę mięsa oraz sensorycznie jego marmurkowatość i jędrność. Wyniki. Oceniane mięso z obu grup: kontrolnej (K) i doświadczalnej (D) cechowało się dobrymi właściwościami technologicznymi, dobrą oceną sensoryczną oraz właściwymi parametrami barwy. Ponadto mięso było kruche, o korzystnym udziale białka i tłuszczu śródmięśniowego.

Wnioski. W pracy nie wykazano ujemnego wpływu zastąpienia w mieszance paszowej poekstrakcyjnej śruty sojowej nasionami roślin strączkowych na uzyskanie mięsa dobrej jakości, bez istotnego zróżnicowania jego parametrów.
\end{abstract}

Słowa kluczowe: nasiona strączkowe, mięso wieprzowe, cechy fizyczne, jakość mięsa

Corresponding address - Adres do korespondencji:

Maria Bocian, Zaktad Hodowli Trzody Chlewnej i Koni, Uniwersytet Technologiczno-Przyrodniczy im. Jana i Jędrzeja Śniadeckich w Bydgoszczy, ul. Mazowiecka 28, 85-084 Bydgoszcz, Poland,e-mail: bocian@utp.edu.pl

Accepted for publication - Zaakceptowano do opublikowania:

3.11.2016

For citation - Do cytowania:

Bocian, M., Kapelański, W., Adamowicz, M., Jankowiak, H., Cebulska, A., Gimińska, A., Mońko, A. (2016). Influence of nutrition of pigs with legume-enriched mixtures on the quality of pork. Nauka Przyr. Technol., 10, 4, \#46. DOI: http://dx.doi.org/10.17306/J.NPT.2016.4.46 